\title{
Toward the Role of EFL/ESL Students' Silence as a Facilitative Element in Their Success
}

\author{
Jing $H u^{*}$ \\ School of College English Teaching and Research, Henan University, Kaifeng, China
}

Following the recent evolution of research perspectives toward student silence, an increasing number of studies have sought to empirically probe into the beneficial role of this variable in students' success. Yet, a limited number of review studies have been carried out to illustrate the complex nature of student silence and its positive consequences (e.g., success, increased learning outcomes, etc.). Hence, this study aims to review different definitions of "student silence" to elucidate its facilitative function in EFL/ESL students' success. Providing empirical evidence, the role of student silence as a facilitative element in English language learning was proved. Finally, some pedagogical implications for EFL/ESL teachers and teacher trainers are also discussed.

Keywords: student silence, facilitative function, EFL/ESL students, success, English language learning

\section{OPEN ACCESS}

Edited by:

Ali Derakhshan,

Golestan University, Iran

Reviewed by:

Ali Zangoei,

University of Gonabad, Iran

Saeed Khazaie,

Isfahan University of Medical

Sciences, Iran

*Correspondence:

Jing Hu

10310092@vip.henu.edu.cn

Specialty section:

This article was submitted to

Educational Psychology,

a section of the journal

Frontiers in Psychology

Received: 06 July 2021

Accepted: 26 July 2021

Published: 16 August 2021

Citation:

Hu J (2021) Toward the Role of EFL/ESL Students' Silence as

a Facilitative Element in Their

Success. Front. Psychol. 12:737123.

doi: 10.3389/fpsyg.2021.737123

\section{INTRODUCTION}

For decades, students' silence in English as a second/foreign language (ESL/EFL) classes had been perceived as a detrimental learning behavior, inhibiting interactions between teachers and students (Wang and Liu, 2021). However, in recent years, several scholars (e.g., Hanh, 2020; Harumi, 2020; Peng, 2020; Tsui and Imafuku, 2020) have suggested that silence may not always be an impediment for students and may rather serve a facilitative function in language learning. In this regard, Harumi and King (2020) have emphasized the need to distinguish the pedagogical roles of silence as a "voluntary productive communicative resource" or a "mode of learning" and of reticence as "withdrawal from learning" (p. 6). In an attempt to characterize the pedagogical role of student silence, Hanh (2020), stated that silence may be beneficial for students' success as it offers more opportunities for reflection and cognition. In the same vein, Harumi (2020) also noted that students' silence on the surface has the potential to promote L2 learning by leaving more space for "attentive listening, thinking, and reformulating ideas" (p. 39).

The notion of silence is literally defined as "the absence of vocalization" (Bosacki, 2005, p. 6). For many previous studies (e.g., Granger, 2004; Liu, 2005, 2006; Liu and Jackson, 2009; Delima, 2012), the concept of student silence had negative connotations. In his study, Granger (2004), for instance, referred to students' silence as "disobedience," "conflict," and "misbehavior." Similarly, Liu and Jackson (2009) also defined student silence as an emotional reaction against the teachers' authority and a means of passively expressing unfavorable feelings. However, with the latest evolution of research perspectives toward student silence, an increasing number of recent studies has adopted positive perspectives to define this concept. According to some studies (e.g., Hanh, 2020; Tsui and Imafuku, 2020), students' silence should not be deemed as an absence of thought or absence of communication but rather it should be considered as another means of communication.

Given the significance of classroom silence in second language learning, several empirical studies have been carried out to investigate the role of this factor in English language learning (e.g., Bista, 2012; Bao, 2014; Banks, 2016; Min, 2016; King and Smith, 2017; Juniati et al., 2018; King et al., 2020; 
Maher and King, 2020; Hongboontri et al., 2021). However, most of the researchers have chosen to probe into the impeditive role of students' silence in their learning. Furthermore, a small number of studies in the form of review have been conducted to explain the multidimensional nature of student silence. Hence, in the current review article, the researcher endeavored to illustrate the concept of student silence, on the one hand, and to elaborate on its facilitative effects on EFL/ESL students' success, on the other hand.

\section{The Concept of Student Silence}

Student silence is an elusive and ambiguous concept with various communicative connotations that cannot be easily characterized. As such, there is a wide range of controversy regarding the definition of this concept. To be more specific, Granger (2004) simply defined student silence as "the mere absence of speech" (p. 3), as opposed to Liu (2002), who characterized this concept as a communicative strategy through which students show respect to their teachers and classmates. As another example, Bruneau (2008) conceptualized student silence as "a lack of communication contact with other classroom participants" (p. 78), whereas Meyer (2009) referred to this concept as another means of communication. Two distinctive attitudes were applied in conceptualizing the notion of student silence. Those who had a negative viewpoint toward student silence characterized it as students' unresponsiveness, inattentiveness, and disengagement in educational contexts (Nakane, 2007; Ping, 2010; Choi, 2015). On the other hand, those who had positive perceptions about students' silence defined this concept as "a voluntary productive communicative resource able to enhance L2 learning opportunities" (Harumi and King, 2020, p. 6).

In an attempt to categorize different types of student silence, Kurzon (2007) classified this variable into two groups, namely intentional silence and unintentional silence. While students' intentional silence is strategic and deliberately employed for certain reasons, their unintentional silence is accidental and unconscious, occurring when a student is extremely anxious or ashamed.

\section{The Facilitative Role of EFL/ESL Students' Silence in Their Success}

Historically, in almost all educational settings, students' verbal behavior has attracted more favorable attention than their silence. More specifically, in second language learning contexts, students' speech as the language output has been the focus of much research. However, considering visible/audible behaviors as the sole language output indicates an extremely simplistic position toward students' advancement (Innocenti, 2002; Galletly and Bao, 2015). In this regard, Bao (2020) noted that based on how silence is deployed, "the occurrence of inner speech in the learner's system deserves to be considered as a type of production, especially when ideas or thoughts are taking shape in the mind" (p. 18). Based on this logic, the place of student silence in EFL/ESL classes has been revisited. That is, several scholars (e.g., Harumi, 2020; Harumi and King, 2020; Karas and Faez, 2020; King et al., 2020; Peng, 2020; Tsui and Imafuku, 2020) re-examined the role of student silence in second language learning. Harumi and King (2020), for instance, referred to student silence as a "mode of learning" that enables students to listen more attentively, which in turn enhances their academic success. Similarly, Harumi (2020) also explained that students' silence as a learning tool can offer more space for students' reflection, resulting in increased learning outcomes. Additionally, King et al. (2020) also suggested that students' intentional silence can give them an invaluable chance to revise and reformulate their ideas, which may help them to overcome their feeling of anxiety. With a low level of anxiety, students are more likely to engage in classroom activities (Liu and Jackson, 2011; King, 2014; Effiong, 2016).

\section{EMPIRICAL STUDIES}

The positive and facilitative role of student silence in English language learning was empirically proved by several recent studies (e.g., Hanh, 2020; Harumi, 2020; Humphries et al., 2020; King et al., 2020; Maher, 2020; Maher and King, 2020; Peng, 2020). For instance, Harumi (2020) investigated classroom silence, its consequences, and different appropriate approaches to interact with this phenomenon. To do this, 56 English language teachers took part in this study. The required data were gathered through observations and open-ended questionnaires. Analyzing the obtained data, the researcher found that students' silence can serve a facilitative function in their success if language teachers know how to interact with it. In another study, Hanh (2020) studied the silent behavior of 85 EFL students who voluntarily participated in the study. Analyzing students' responses to the questionnaire and interview questions, the researcher evinced what factors contribute to students' silence and how the silent behavior of students can promote their learning. Besides, to this end, King et al. (2020) probed EFL students' silence in relation to their sense of anxiety. In so doing, structured classroom observations, self-report reflection sheets, and stimulated recall interviews were employed to collect data. In light of the results of analyses, the researchers explained in what ways students' intentional silence can reduce their sense of anxiety.

\section{CONCLUSION AND PEDAGOGICAL IMPLICATIONS}

In this review article, the concept of student silence, its distinctive definitions, its different types (i.e., intentional, unintentional), and its positive consequences (i.e., success, increased learning outcomes) were explained. Furthermore, some empirical studies conducted on student silence were also summarized to prove the positive effects of students' silence on their learning outcomes. According to what was theoretically and empirically reviewed, it can reasonably be inferred that the silent behavior of students can play a pivotal role in their academic success only if it is appropriately utilized and managed by classroom participants (i.e., teachers, students). The implications emerging from this 
review relate specifically to EFL/ESL teachers. First and foremost, teachers should not perceive students' intentional silence as their academic disengagement since they typically employ silence to think, reflect, and listen more attentively (Harumi and King, 2020). Second, teachers should not push their students to talk as it may increase their sense of fear and anxiety (King, 2014; King and Smith, 2017). Besides, the findings of this review have some pedagogical implications for teacher trainers. Given the significance of the silent behavior of students in their success (Maher, 2020; Maher and King, 2020; Peng, 2020; Tsui and Imafuku, 2020), teacher trainers should alter teachers' attitudes toward this phenomenon and instruct them how to appropriately interact with their students' silence.

\section{REFERENCES}

Banks, S. (2016). Behind Japanese students' silence in English classroom. Accents Asia 8, 54-75.

Bao, D. (2014). Understanding Silence and Reticence: ways of Participating in Second Language Acquisition. London: Bloomsbury.

Bao, D. (2020). "Silence, talk and in-betweens: east Asian students' responses to task challenge in an Australian University" in East Asian Perspectives on Silence in English Language Education. eds J. King and S. Harumi (Bristol: Multilingual Matters). 17-36. doi: 10.21832/9781788926775-007

Bista, K. (2012). Silence in teaching and learning: perspectives of a Nepalese graduate student. Coll. Teach. 60, 76-82. doi: 10.1080/87567555.2011.6 33943

Bosacki, S. L. (2005). The Culture of Classroom Silence. New York: Peter Lang.

Bruneau, T. J. (2008). How Americans use silence and silences to communicate. China Media Res. 4, 77-85.

Choi, J. Y. (2015). Reasons for silence: a case study of two Korean students at a US graduate school. TESOL J. 6, 579-596. doi: 10.1002/tesj.209

Delima, E. M. (2012). A reticent student in the classroom: a consequence of the art of questioning. Asian EFL J. 60, 51-69.

Effiong, O. (2016). Getting them speaking: classroom social factors and foreign language anxiety. TESOL J. 7, 132-161. doi: 10.1002/te sj. 194

Galletly, R., and Bao, C. (2015). Listening to student silence in transnational Education. Engl. Lang. Teach. China 6, 9-15.

Granger, C. A. (2004). Silence in Second Language Learning: a Psychoanalytic Reading. Bristol: Multilingual Matters.

Hanh, N. T. (2020). Silence is gold?: a study on students' silence in EFL classrooms. Int. J. High. Educ. 9, 153-160. doi: 10.5430/ijhe.v9n $4 \mathrm{p} 153$

Harumi, S. (2020). "Approaches to interacting with classroom silence: the role of teacher talk" in East Asian Perspectives on Silence in English Language Education. eds J. King and S. Harumi (Bristol: Multilingual Matters), 37-59. doi: 10.21832/ 9781788926775-008

Harumi, S., and King, J. (2020). "East Asian perspectives on silence in English language education: an introduction" in East Asian Perspectives on Silence in English Language Education. eds J. King and S. Harumi (Bristol: Multilingual Matters). 1-16. doi: 10.21832/9781788926775-006

Hongboontri, C., Wittaya, I., and Booyaprakob, K. (2021). Silence in an EFL classroom: the interplay of Schwab's four commonplaces. Suranaree J. Soc. Sci. $15,128-146$

Humphries, S., Akamatsu, N., Tanaka, T., and Burns, A. (2020). "Silence in Japanese classrooms: activities and factors in capacities to speak English" in East Asian Perspectives on Silence in English Language Education. eds J. King and S. Harumi (Bristol: Multilingual Matters). 123-142. doi: 10.21832/9781788926775-012

Innocenti, D. (2002). "The mind's eyes view: teaching students how to sensualize language" in Language and Image in the Reading-writing Classroom: teaching Vision. eds K. S. Fleckenstein, L. T. Calendrillo, and D. A. Worley (Mahwah: Lawrence Erlbaum Associates). 59-69.

\section{AUTHOR CONTRIBUTIONS}

$\mathrm{JH}$ composed this review independently and revised it before it was submitted.

\section{FUNDING}

This work was the part of the Teaching Reform Project supported by Henan University, with the project title College Ideological Political Education Construction and Evaluation System Under the Background of the Three Whole-person- A Case of College English Teaching (grant no. HDXJJG2020-40).

Juniati, S. R., Jabu, B., and Salija, K. (2018). "Students' silence in the EFL speaking classroom" in Paper Presented at Proceedings of the 65th TEFLIN International Conference. (Indonesia: Universitas Negeri Makassa).

Karas, M., and Faez, F. (2020). "Communicative language teaching and silence: chinese (pre-service) teachers' perspectives" in East Asian Perspectives on Silence in English Language Education. eds J. King and S. Harumi (Bristol: Multilingual Matters). 105-122. doi: 10.21832/978178892 6775-011

King, J. (2014). "Fear of the true self: social anxiety and the silent behavior of Japanese learners of English," in The Impact of Self-concept on Language Learning. eds K. Csizér and M. Magid (Bristol: Multilingual Matters). 232-249. doi: 10.21832/9781783092383-014

King, J., and Smith, L. (2017). "Social anxiety and silence in Japan's tertiary foreign language classrooms," in New Insights into Language Anxiety. eds C. Gkonou, M. Daubney and J.-M. Dewaele. (Bristol: Multilingual Matters). 91-109. doi: 10.21832/9781783097722-007

King, J., Yashima, T., Humphries, S., Aubrey, S., and Ikeda, M. (2020). "Silence and anxiety in the English-medium classroom of Japanese universities: a longitudinal intervention study" in East Asian Perspectives on Silence in English Language Education. eds J. King and S. Harumi (Bristol: Multilingual Matters). 60-79. doi: 10.21832/9781788926775-009

Kurzon, D. (2007). Towards a typology of silence. J. Pragmat. 39, 1673-1688. doi: 10.1016/j.pragma.2007.07.003

Liu, J. (2002). Negotiating silence in American classrooms: three Chinese cases. Lang. Int. Commun. 2, 37-54. doi: 10.1080/147084702086 68074

Liu, M. (2005). Reticence in oral English language classrooms: a case study in China. TESL Rep. 38, 1-16. doi: 10.5539/elt.v12n4p1

Liu, M. (2006). Reticence in oral English classrooms: causes and consequences. Asian J. Engl. Lang. Teach. 16, 45-66.

Liu, M., and Jackson, J. (2009). Reticence in Chinese EFL students at varied proficiency levels. TESL Can. J. 26, 65-81. doi: 10.18806/tesl.v26 i 2.415

Liu, M., and Jackson, J. (2011). "Reticence and anxiety in oral English lessons: a case study in China" in Researching Chinese Learners. eds L. Jin and M. Cortazzi (Basingstoke: Palgrave Macmillan), 119-137. doi: 10.1057/978023029 9481_6

Maher, K. (2020). "Examining L2 learners' silent behavior and anxiety in the classroom using an approach based on cognitive-Behavioral theory" in East Asian Perspectives on Silence in English Language Education. eds J. King and S. Harumi (Bristol: Multilingual Matters). 80-104. doi: 10.21832/9781788926775010

Maher, K., and King, J. (2020). Observing Anxiety in the Foreign Language Classroom: student Silence and Nonverbal Cues. J. Psychol. Lang. Lear. 2, 116-141. doi: 10.52598/jpll/2/1/6

Meyer, K. R. (2009). Student Classroom Engagement: rethinking Participation Grades and Student Silence. United States: Ohio University.

Min, H. (2016). A study on silence phenomenon in the college English classroom. Int. J. Educ. Res. 4, 451-458. 
Nakane, I. (2007). Silence in Intercultural Communication: perceptions and Performance. Amsterdam: John Benjamins Publishing.

Peng, J. E. (2020). "Willing silence and silent willingness to communicate (WTC) in the Chinese EFL classroom: a dynamic systems perspective" in East Asian Perspectives on Silence in English Language Education. eds J. King and S. Harumi (Bristol: Multilingual Matters). 143-165. doi: 10.21832/978178892 6775-013

Ping, W. (2010). A case study of an in-class silent postgraduate Chinese student in London Metropolitan University: a journey of learning. TESOL J. 2, 207-214.

Tsui, A. B., and Imafuku, R. (2020). "Conclusion: silence in EFL classrooms revisited" in East Asian Perspectives on Silence in English Language Education. eds J. King and S. Harumi (Bristol: Multilingual Matters). 166-181. doi: 10. 21832/9781788926775-014

Wang, P., and Liu, H. (2021). Book Review: east Asian perspectives on silence in English language education. Front. Psychol. 11:3827. doi: 10.3389/fpsyg.2020. 631209
Conflict of Interest: The author declares that the research was conducted in the absence of any commercial or financial relationships that could be construed as a potential conflict of interest.

Publisher's Note: All claims expressed in this article are solely those of the authors and do not necessarily represent those of their affiliated organizations, or those of the publisher, the editors and the reviewers. Any product that may be evaluated in this article, or claim that may be made by its manufacturer, is not guaranteed or endorsed by the publisher.

Copyright $\odot 2021 \mathrm{Hu}$. This is an open-access article distributed under the terms of the Creative Commons Attribution License (CC BY). The use, distribution or reproduction in other forums is permitted, provided the original author(s) and the copyright owner(s) are credited and that the original publication in this journal is cited, in accordance with accepted academic practice. No use, distribution or reproduction is permitted which does not comply with these terms. 